\title{
ANALISIS PENGARUH KOMITMEN ORGANISASI TERHADAP SEMANGAT KERJA PEGAWAI KANTOR DINAS PERTANIAN KOTA BIMA
}

\author{
Wardimansyah $^{1}$, Wulandari ${ }^{2}$ \\ ${ }^{1-2}$ STIE Bima \\ 1. ${ }^{\text {dimanslankers@gmail.com, }}{ }^{2}$ wulan.stiebima@gmail.com
}

\begin{abstract}
This study aims to determine the effect of organizational commitment on employee morale in the Agriculture Office of the City of Bima. The criteria set by the researcher as the sample in this study were the employees of the Civil Service Office (ANS) at the main service with a total of 61 people using purposive sampling technique, namely the method of selecting samples based on certain criteria. Based on the results of data processing using SPSS version 23.0, the following results were obtained: This type of research is associative with a population of 52 employees based on the Slovin formula. The constant value is positive at 22.559 and the oefficient of organizational commitment variable is 0.378 , so the regression equation can be written: $Y=22.559+0.378 X$, and the correlation coefficient $(R)=0.222$. This means that the variable organizational commitment $(X)$ in explaining the morale variable $(Y)$ is in the low category. $R$ Square value of 0.049 . This means that the contribution of the organizational commitment variable $(X)$ to morale $(Y)$ is $0.49 \%$, while $46.5 \%$ is influenced by variables outside of this research model. For the t-test, two parties reject the alternative hypothesis $(\mathrm{Ha})$ which states that organizational commitment has no effect on morale in the agricultural department of the city of Bima (HO is accepted).
\end{abstract}

Keywords : Organizational Commitment, Morale

\begin{abstract}
ABSTRAK
Penelitian ini meneliti bertujuan untuk mengetahui pengaruh komitmen organisasi terhadap semangat kerja pegawai di Dinas Pertanian Kota Bima. Adapun kriteria yang ditetapkan oleh peneliti sebagai sampel pada penelitian ini adalah pegawai Aparatur Sipil Negeri (ANS) pada dinas induk yang berjumah 61 orang menggunakan teknik purposive sampling yaitu metode pemilihan sampel berdasarkan pada kriteriakriteria tertentu. Berdasarkan hasil pengolahan data menggunakan SPSS versi 23.0, di peroleh hasil sebagai berikut : Jenis penelitian ini adalah asosiatif dengan jumlah populasi sebesar 52 orang pegawai berdasarkan rumus slovin. Nilai konstanta bernilai positif sebesar 22,559 dan oefisien variabel komitmen organisasi sebesar 0,378 , sehingga persamaan regresinya dapat di tulis : $\mathrm{Y}=22,559+0,378 \mathrm{X}$, dan koefisien korelasi $(R)=0,222$. Hal ini berarti variabel komitmen organisasi $(X)$ dalam menjelaskan variabel semangat kerja $(Y)$ berada dalam kategori rendah. Nilai $\mathrm{R}$ Square 0,049. Artinya kontribusi variabel komitmen organisasi (X) terhadap semangat kerja (Y) sebesar $0,49 \%$, sedangkan 46,5\% dipengaruhi oleh variabel diluar model penelitian ini. Untuk uji $\mathrm{t}$ dua pihak menolak hipotesis alternatif $(\mathrm{Ha})$ yang menyatakan bahwa komitmen organisasi tidak berpengaruh terhadap semangat kerja di dinas pertanian kota Bima (H0 diterima).
\end{abstract}

Kata Kunci: Komitmen Organisasi, Semangat Kerja

\section{PENDAHULUAN}

Filosofi pembangunan bangsa sudah lama menempatkan manusia sebagai subjek pembangunan dan bukan lagi objek pembangunan semata. Bertitik tolak pada peran sumber daya manusia yang sangat penting bagi perkembangan suatu institusi, maka perlu adanya pembinaan dalam upaya meningkatkan peran aktif karyawan (Fatimah, 2015). Semangat kerja adalah salah satu indikator penting dalam diri karyawan/pegawai yang perlu ada, sebab dengan semangat kerja pegawai akan menimbulkan dampak postifi bagi kelangsungan dan tujuan dari suatu institusi. Salah satu hal paling penting dalam upaya memupuk semangat kerja pegawai yaitu dengan memastikan adanya komitmen dalam sebuah institusi/organisasi. Menurut Setiawan dan Akhmad (2018) Komitmen 
organisasi menjadi dorongan bagi pegawai untuk bekerja lebih baik atau malah sebaliknya. Oleh sebab itu pegawai dengan komitmen organisasi yang kuat akan membuat loncatan signifikan dalam penyelesaian tugas dan tanggung jawab pada organisasi (Susanti dan Edi, 2018).

Oleh sebab itu komitmen organisasi tidak hanya harus dimiliki oleh karyawan/pegawai pada perusahaanperusahaan besar, tetapi pada semua jenis organisasi, khususnya di instansi pemerintahan yang merupakan institusi pelayanan publik. Fenomena yang penulis amati bahwa di instansi pemerintahan, khususnya daerah pengamatan peneliti yaitu di kota Bima, semangat kerja pegawai tidak begitu tinggi. Sepinya ruang pelayanan, jamjam kantor yang tidak terisi dengan pegawai menunjukkan indikasi tersebut. Melalui wawancara dengan salah satu pegawai ASN di Dinas Pertanian Kota Bima yang dirahasiakan namanya mengungkapkan bahwa indikasi menurunnya semangat kerja nampak pada pegawai di Dinas Pertanian Kota Bima. Indikasi menurunnya semangat kerja disinyalir akibat dari adanya beberapa goncangan eksternal seperti demo yang kerap kali terjadi di kantor tersebut sehingga pegawai malas untuk masuk kantor dan kondisi tersebut berulang kali terjadi. Robbins dan Judge (2009:100) mengemukakan bahwa komitmen organisasi menjadi salah satu dorongan pegawai bekerja lebih baik atau malah sebaliknya justru meninggalkan pekerjaannya, akibat suatu tuntutan komitmen lainnya.

Berdasarkan uraian di atas, maka penulis tertarik untuk melakukan penelitian dengan judul “Analisis Pengaruh Komitmen Organisasi Terhadap Semangat Kerja Pegawai Kantor Dinas pertanian Kota Bima”.

\section{METODOLOGI PENELITIAN}

Jenis penelitian ini adalah asosiatif, di mana penelitian asosiatif merupakan suatu pernyataan yang menunjukkan dugaan tentang hubungan antara komitmen organisasi (X) terhadap semangat kerja (Y).

Menurut Sugiyono (2017) populasi adalah wilayah generalisasi yang terdiri atas objek/subjek yang memiliki kualitas dan karakteristik tertentu yang ditetapkan oleh peneliti untuk dipelajari dan ditarik kesimpulannya. Dalam penelitian ini jumlah populasi sebesar 61 orang pegawai.

Menurut Sugiyono (2017) sample adalah bagian dari jumlah karakteristik yang dimiliki oleh populasi tersebut. Dlama penelitian ini rumus untuk menghitung sample menggunakan Slovin dengan perhitungan sebagai berikut :

$$
n=\frac{N}{1+\left(N \cdot e^{2}\right)}
$$

Di mana :

$\mathrm{n}$ : ukuran sample

$\mathrm{N}$ : ukuran populasi

$\mathrm{E}$ : tingkat kesalaan $5 \%$

$$
\begin{gathered}
n=\frac{61}{1+\left(61.0,05^{2}\right)} \\
n=\frac{61}{1+(0,1525)} \\
n=\frac{61}{1,, 1525} \\
n=52
\end{gathered}
$$

Dari perhitungan di atas maka ditemukan jumlah sample dalam penelitian ini yaitu sebanyak 52 orang.

Teknik sampling yang digunakan dalam penelitian ini yaitu sampling purposive Menurut Sugiyono (2017) sampling purposive adalah teknik penentuan sample dengan pertimbangan tertentu. Dalam penelitian ini hanya diambil sample dari 
pegawai ASN sebab menurut peneliti, komitmen organisasi dan semangat kerja cenderung dimiliki oleh pegawai tetap dan telah cukup lama mengabdi di instansi tersebut. Sehigga dalam penelitian ini hanya akan digunakan responden yang berstatus ASN.

Instrumen penelitian yang digunakan dalam penelitian ini dibantu oleh penggunaan skala likert, yaitu cara untuk memberi bobot/nilai pada setiap pertanyaan dari indikator variabel yang digunakan. Keterangan bobot/nilai tersebut adalah sebagai berikut :

Tabel 1. Skala Instrumen Pengukuran

\begin{tabular}{|l|c|}
\hline \multicolumn{1}{|c|}{ Skala } & Bobot \\
\hline Sangat Setuju (SS) & Lima (5) \\
\hline Setuju (S) & Empat (4) \\
\hline
\end{tabular}

\section{HASIL DAN PEMBAHASAN}

1. Uji Validitas

Tabel 2. Hasil Uji Validitas

\begin{tabular}{|c|c|c|c|c|}
\hline Variabel & Item & Nilai Validity & StandarValiditas & Ket \\
\hline \multirow{4}{*}{$\begin{array}{c}\text { Komitmen } \\
\text { Organisasi }\end{array}$} & 1 & 0,363 & 0,300 & Valid \\
\cline { 2 - 5 } & 2 & 0,310 & 0,300 & Valid \\
\cline { 2 - 5 } & 3 & 0,426 & 0,300 & Valid \\
\cline { 2 - 5 } & 4 & 0,536 & 0,300 & Valid \\
\cline { 2 - 5 } & 5 & 0,360 & 0,300 & Valid \\
\cline { 2 - 5 } & 6 & 0,385 & 0,300 & Valid \\
\cline { 2 - 5 } & 7 & 0,387 & 0,300 & Valid \\
\cline { 2 - 5 } & 8 & 0,363 & 0,300 & Valid \\
\cline { 2 - 5 } Semangat & 2 & 0,379 & 0,300 & Valid \\
\cline { 2 - 5 } & 3 & 0,391 & 0,300 & Valid \\
\cline { 2 - 5 } & 4 & 0,454 & 0,300 & Valid \\
\cline { 2 - 5 } & 5 & 0,304 & 0,300 & Valid \\
\cline { 2 - 5 } & 6 & 0,358 & 0,300 & Valid \\
\cline { 2 - 5 } & 7 & 0,384 & 0,300 & Valid \\
\cline { 2 - 5 } & 8 & 0,342 & 0,300 & 0,300 \\
\hline
\end{tabular}

Tabel 3 di atas menunjukkan bahwa corrected item-total correlation > 0,300. hasil pengujian validitas pada kedua variabel yaitu komitmen organisasi (X), semangat kerja (Y) dapat dikatakan valid pada Hasil pengujian validitas ini menunjukkan bahwa pernyataan kuesioner dalam penelitian ini valid.

2. Uji Reliabelitas

Tabel 3. Hasil Uji Reliabelitas

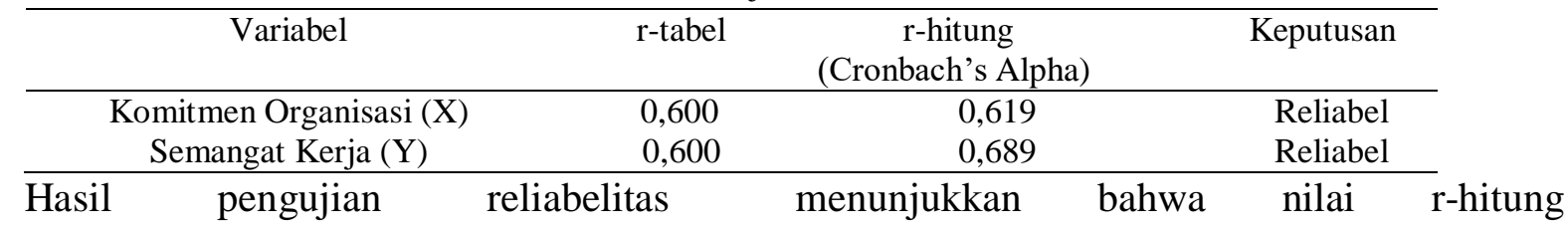


(cronbach's alpha) untuk variabel komitmen organisasi sebesar $(0,619)$, dan semangat kerja sebesar $(0,689)$ lebih besar $(>)$ dari nilai r-tabel sebesar 0,600. Hal ini menunjukkan bahwa instrumen dapat mengukur item pertanyaan secara konsisten dari waktu ke waktu.

3. Hasill Uji Regresi Linier Berganda

Tabel 4. Hasil Pengujian Regresi Linier

\section{Coefficients $^{\mathrm{a}}$}

\begin{tabular}{|c|c|c|c|c|c|c|}
\hline \multirow[b]{2}{*}{ Model } & \multicolumn{3}{|c|}{$\begin{array}{l}\text { Unstandardized } \\
\text { Coefficients }\end{array}$} & \multirow{2}{*}{$\begin{array}{r}\text { Standardized } \\
\text { Coefficients } \\
\text { Beta }\end{array}$} & \multirow[b]{2}{*}{$\mathrm{t}$} & \multirow[b]{2}{*}{ Sig. } \\
\hline & & B & Std. Error & & & \\
\hline & (Constant) & 22.559 & 9.041 & & 2.495 & .016 \\
\hline 1 & $X$ & .378 & .236 & .222 & 1.607 & .114 \\
\hline
\end{tabular}

a. Dependent Variable: $Y$

$\mathrm{Y}=22,559+0,378 \mathrm{X}$

1. Nilai konstanta bernilai positif sebesar 22,559. Hal ini menunjukkan apabila komitmen organisasi konstan, maka kepuasan kerja mengalami peningkatan sebesar 22,559.

2. Koefisien regresi variabel komitmen organisasi bernilai positif sebesar 0,378 hal ini menunjukkan bahwa apabila komitmen organisasi meningkat, maka hal tersebut dapat meningkatkan kepuasan kerja sebesar 0,378 .

a. Kofisien Determinasi

Tabel 5. Hasil Koefisien Determinasi dan Koefisien Korelasi

$$
\text { Model Summary }{ }^{b}
$$

\begin{tabular}{|c|c|c|c|c|}
\hline Model & $\mathrm{R}$ & R Square & $\begin{array}{l}\text { Adjusted R } \\
\text { Square }\end{array}$ & Std. Error of the Estimate \\
\hline 1 & $.222^{\mathrm{a}}$ & .049 & .030 & 2.081 \\
\hline
\end{tabular}

Nilai koefisien determinasi dapat dilihat pada Tabel 6 dengan nilai R- square sebesar 0,049. Artinya kontribusi variabel komitmen organisasi $(\mathrm{X})$ terhadap semangat kerja (Y) sebesar 0,49\%, dengan kata lain sebesar 99,51\% variabel semengat kerja di dinas pertanian kota Bima dipengaruhi oleh variabel lain.

b. Koefisien Korelasi

Nilai koefisien korelasi yang ditunjukkan oleh nilai $\mathrm{R}$ pada Tabel 6yaitu sebesar 0,222 Berdasarkan kriteria koefisien korelasi, kekuatan asosiatif variabel komitmen organisasi (X) dalam menjelaskan variabel semangat kerja (Y) berada dalam kategori rendah

c. Uji Hipotesis t

Tabel 7.

Coefficients $^{\text {a }}$

\begin{tabular}{|c|c|c|c|c|c|c|}
\hline \multirow[b]{2}{*}{ Model } & & \multicolumn{2}{|c|}{$\begin{array}{l}\text { Unstandardized } \\
\text { Coefficients }\end{array}$} & \multirow{2}{*}{$\begin{array}{r}\text { Standardized } \\
\text { Coefficients } \\
\text { Beta }\end{array}$} & \multirow[b]{2}{*}{$\mathrm{t}$} & \multirow[b]{2}{*}{ Sig. } \\
\hline & & B & Std. Error & & & \\
\hline \multirow[b]{2}{*}{1} & (Constant) & 22.559 & 9.041 & & 2.495 & .016 \\
\hline & $X$ & .378 & .236 & .222 & 1.607 & .114 \\
\hline
\end{tabular}

a. Dependent Variable: Y 


\section{H1 : Komitmen organisasi tidak berpengaruh terhadap semangat kerja di dinas pertanian kota Bima}

Hasil statistik uji $\mathrm{t}$ untuk variabel semangat kerja $(\mathrm{X})$ memperoleh nilai t-hitung sebesar 1,607 dengan nilai t-tabel sebesar 1,674 $(1,607<1,674)$, maka hipotesis H1 yang menyatakan bahwa komitmen organisasi tidak berpengaruh terhadap semangat kerja di dinas pertanian kota Bima (H0 diterima).

\section{KESIMPULAN}

Komitmen organiasasi tidak berpengaruh terhadap semangat kerja di dinas pertanian kota Bima.

\section{DAFTAR PUSTAKA}

Fatimah, Siti. 2015. Pengaruh Stres Kerja dan Komitmen Organisasi Terhadap Semangat Kerja Karyawan PT. BPR Indomitra Mega Kapital Pekanbaru. Jurnal Jom FEKOM Vol. 2 No. 2 Oktober 2015.

Hasibuan, S.P. Malayu. 2009. Manajemen Sumber Dya Manusia, Cetakan ketujuh.

Jakarta: PT Bumi Aksara.

Nitisemito, 2009, Manajemen Personalia: Manajemen Sumber Daya Manusia, Ghalia Indonesia, Jakarta.

Robbins SP, dan Judge. 2009. Perilaku Organisasi Buku 2, Jakarta : Selemba Empat.

Setiawan, Nashrudin dan Akhmad Taufik. 2018. Analisis Komitmen Organisasi, Iklim Kerja dan Pengembangan Karir Terhadap Semangat Kerja Karyawan Di Universitas Pembangunan Panca Budi Medan. Jurnal Manajemen Tools Vol. 10 No. 2 Desember 2018.

Susanti, Elsi dan Edi Haskar. 2018. Pengaruh Komitmen Kerja dan Disiplin Kerja Terhadap Semangat Kerja Dosen
UMSB. Jurnal Menara Ilmu Vol XII. No. 10 Oktober 2018.

Sugiyono. 2017. Metode Penelitian Bisnis, Pendekatan Kuantitatif, Kualitatitif, Kombinasi, dan R\&D. Bandung: Penerbit Alfabeta. 